\title{
Value and Role of Multinational Corporations in Processes of Globalization of Economy and their Influence on Economic Security of the Country
}

\author{
Rakhimova G.S. \\ Department Finance and Credit \\ University of management "TISBI" \\ Kazan, Russia \\ guzelrahimova@mail.ru \\ Shipshova O.A. \\ Department of Economics and Innovation \\ Kazan cooperative institute "Russian University of \\ Cooperation" \\ Kazan, Russia \\ os69@bk.ru
}

\author{
Mukhametshina F.A. \\ Department of Economic Theory and Resource \\ Management \\ Kazan national research technical university of A.N. \\ Tupoleva-KAI" \\ Kazan, Russia \\ farida1973@yandex.ru
}

Syurkova S.M.

Department Finance and Credit

University of management "TISBI"

Kazan, Russia

syurkova@mail.ru

\section{RESEARCH METHODOLOGY}

\begin{abstract}
The role and value of multinational corporations in the processes of economy globalization and their influence on the level of economic security of the country are explored in this article. Main threats which arise in the course of activity of multinational corporations (multinational corporation) in domestic markets of the country are considered. Authors made the analysis methodological and aspects of emergence of multinational corporations and separate stages of their development. Also during the research the main competitive advantages of multinational corporation which lead to improvement of production forces were revealed and promote strengthening of economy globalization and the world competitive relations.
\end{abstract}

Keywords-economic security; multinational corporations; external and internal threats.

\section{INTRODUCTION}

Nowadays when globalization of economy happens more and more with high speed, the economic impact of multinational corporations on economy of various countries amplifies, questions of national economic security and independence of the state have become of great value. Questions of national economic security are one of vital development of Russia in the form of the sovereign united country. The problem of economic security never existed by itself. It come from problems of economic growth at each step of society development and one of the most important functions of any country involving economic security in various directions of social, economic and political life.

\section{A. Research purpose}

To consider a role of multinational corporations in a condition of economy globalization and their influence on a condition of national economic security; to analyze the threats connected with the strengthening of multinational corporations pressure upon economic processes in Russia to reveal a role of the state in regulation of national security issues.

Initial data for this article is independent conclusions of authors and also handling of other authors results of research. This research is based on the thesis that economic security of the country can be subject to internal and external threats in the course of globalization and increase a role of multinational corporations in economies of the certain states. The methodology of the research includes analysis and structuring of the facts confirming this hypothesis.

\section{RESULTS}

Economic security is the most important part of national state security, it is material and financial basis. Providing the stable high level of economic security is an exclusive prerogative of the state. According to works of Russian and foreign economists economic security represents the system of ensuring stability of national economy, preserving its integrity, capability and self-development, despite the arising external and internal threats. The country in that case will have a high 
level of economic security when the government and authorities' institutions can realize various methods and mechanisms which allow not only to protect and support national economy, but also to develop it to higher level. In general, one may say, that economic security of any country is a relative concept, it is connected with the fact that even in the most advanced and socially stable countries with a steady political regime there can periodically be various external and internal threats and adverse effects reducing the level of economic security. In the course of economy globalization and internationalization of production, inclusion of national economy in the world economy, economic security of the country contacts with the international economic security more and more closely [9, P 173]. At the same time there are more and more key reasons which can break integrity of economic security of the country, and the main objective of the government in this case is to reduce or to absolutely exclude external and internal threats in the influence zone.

The problem of economic security comes from problems of economic growth at each stage of society development. Nowadays extent of society development is characterized by globalization processes in all spheres of life that is followed by availability of a large number of multinational companies (multinational corporation) in various sectors of the economy and their influence on many sectors of society activity and first of all on the level of economic security of the country.

From our point of view, increasing of an economic role of multinational corporations keeps both benefits to national economies and certain threats to its sovereignty, loss of independence, dependence on the foreign capital.

The present stage of development of multinational companies began during the 1990th years. By this time the history of the international capital existed for more than three hundreds years. At the end of the twentieth century there were large American, Japanese and Korean IT-companies which began to use actively information technologies, making transactions by means of computer and Internet technologies to the economic and industrial world. Penetration of information technologies into other industries and sectors of activity, such as finance, trade, insurance, etc. led to the fact that all developed world economies passed into a cyberspace, and multinational companies which were engaged in industrial production began to perform large investments into the knowledge-intensive industries. During the period from 1970 to the 1990th year the number of multinational corporation increased from 7000 to 60000 [8, page 11]. At the same time, considering impact of multinational corporations on world economy in general, it should be noted that they subordinated the whole industries of production in scale of the certain countries and regions and the world economy that decrease the level of economic security by this criteria and in various countries demonstrates dependence of national producers on the large international capital as a result.

Now the large number of multinational corporations is registered in developed countries and quickly developing China, on chart 1 we can see distribution of 100 leading (according to Forbs for 2017) multinational corporations in the world macroregions [4].

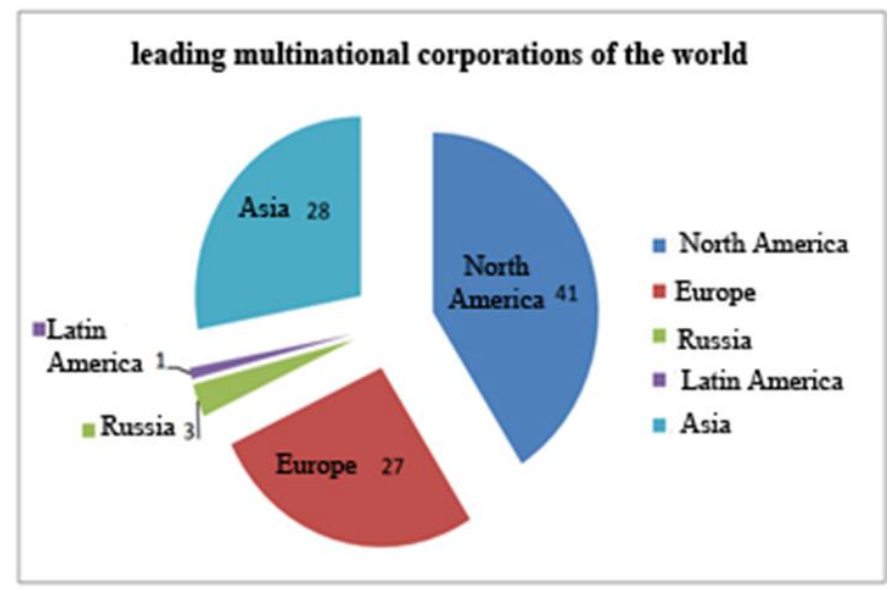

Fig. 1. Distribution of 100 leading multinational corporations of the world in world regions.

As we can see from the provided chart, the considerable number of the leading multinational corporations is located in the territory of North America (USA), Europe and Asia and occupy almost identical market shares. Russian multinational corporations occupy only $3 \%$ in this list and which, by the way, approximately equals shares of Russia in universal GDP.

According to chart 2, vast majority of corporations of the production sector are the share of the USA and Japan, and the rest is divided on countries of Western Europe.

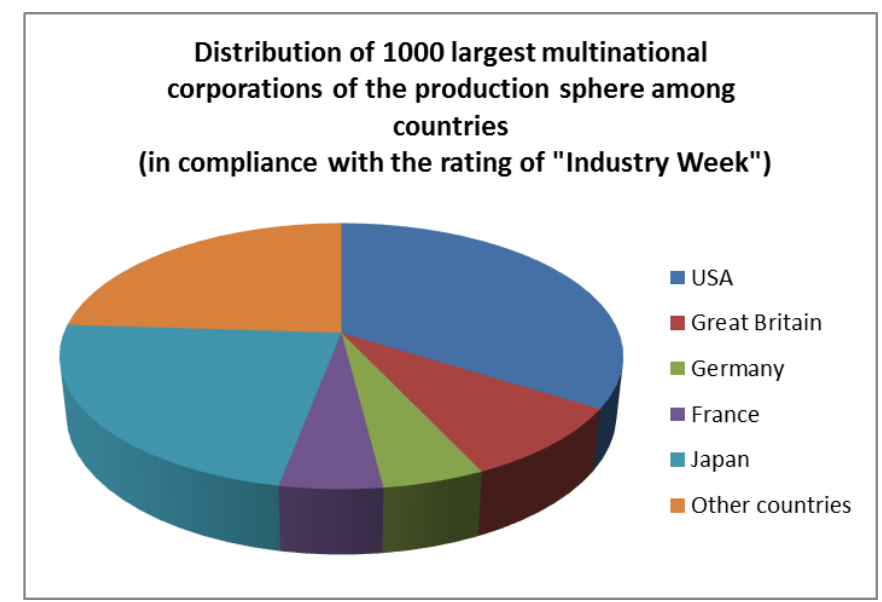

Fig. 2. Distribution of 1000 largest multinational corporations of the production sector among countries

Nowadays, the largest world multinational corporations were reoriented on conducting activity and the competition in global planetary scale. Their globality is shown that both production, and geography of their activity extends at the same time on several terrestrial continents, and their economic target is optimization of activity and enhancement of profit due to suppression of small enterprises in weaker countries. Thus, the transnational capital creates several threats for national economic security for weaker countries at once including:

- strengthening of import dependence on food and consumer goods 
distribution of world resources and the international job specialization as each country has the specific weight in production and production of resources. Optimizing production on a global scale and trying to obtain minimum costs for production factors, multinational corporations have huge competitive advantage on decrease in prime cost of goods. Using the financial power, multinational corporations create production in other countries, attracting cheaper local labor power and crossing customs barriers which the government sometimes creates for protection of domestic market against import goods. This situation can be expedient at obvious attractiveness of the new market whereas direct commodity importation would not be profitable because of the raised import went to finished goods or high transportation costs.

In order to avoid problems with the governments of the states and charges of monopolism the international corporations seek to concentrate the resources mainly in those countries where there is lowest tax law, low customs duties and transfer prices that allow them to evade from payment of a part of taxes and fees. It is also necessary to note also the fact that at formation of multinational corporations in various countries the dominating role is played by different factors. So, in the USA generally it is a financial capital, in Japan it is an organic interlacing of the large companies. In South Korea, in Japan, France and other countries the coordinating role of the state is in activity of national corporations. [8, P. 15] They encourage the governments of developed countries to let the large and branched corporations: tax benefits on profit, contracts through the operating contract system and priority participation in state programs. For the firms working for the military market it is mitigated or the antitrust law is completely repealed and also export quotas and privileges are provided. All these factors in total allow them to win new markets and countries and to be stable during the crisis phenomena.

\section{DISCUSSION}

However, it is impossible to consider multinational companies only from the negative point of view and only as threat to internal sovereignty and economic security of the country. As for value of multinational corporations for world economy, as a rule, they have considerable competitive advantages including huge financial and material resources and have a well-known trademark in the world, their products are in great demand for consumers of various countries and regions, large financial resources allow multinational corporations to conduct large-scale marketing researches which are directed to market research detecting needs of consumers [6, P 151]. Multinational corporations save considerable means on production scales and the share of fixed costs decreases with the expansion of production scales, therefore, the product cost decreases and it gives to the company chance to regulate the price depending on the market situation.

Multinational corporations often use cheaper resources and raw materials of other countries that on the one hand allows to reduce product cost, and from another leads to exhaustion of resources of the countries and as a result creates threat of resource security. It happens because of uneven

\section{CONCLUSIONS}

This research allowed to make the following conclusions: in modern conditions when globalization of economy happens more and more with high speed, the economic impact of multinational corporations amplifies economy of various countries. Multinational companies along with possession of clear competitive advantages can bring threats to economic security of weaker countries. The state government has to take measures for regulation of access of multinational corporation to the domestic market of the country and protect the interests of local producers pursuing protectionism.

Thus, in this article the role and value of multinational corporations in processes of globalization of economy, and their influence on the level of economic security of the country were investigated. The main threats which arise in the course of activity of multinational corporations in domestic markets of the country are considered.

\section{References}

[1] Velichko A. S. Stages of development of multinational corporations and criteria of reference of the companies to multinational corporation. 
[6] Ogorodnikova Y.G., Rakhimova G.S., Varenik S.S. Clusters and their Current trends of development of science and technologies. 2017, 2-6, pp. $40-42$.

[2] Kostyleva A. V., Bychkova L. V. A role of multinational corporations in world economy. the Young scientist. 2017, 2, pp. 450-453. - URL https://moluch.ru/archive/136/38254/.

[3] Kuznetsova, E.I. Economic security and competitiveness. Forming of economic strategy of the state. Monograph. Signature stamp of UMTs "Professional Textbook". Signature stamp of scientific research institute of science and education. M.: YUNITI. 2017, pp. 239.

[4] Lopatin E.Y. Updating of a definition "multinational corporation" in modern conditions. International research magazine. 2015, 7-3(38), pp. 64-67.

[5] Maximov S.N. Economic security of Russia: system and legal research. M.: MPSI, MODEK. 2018, pp.56. pp. $150-155$.

[7] Suglobov A.E. Economic security of the enterprise: The education guidance for students of higher education institutions, students in "Economic security". M.: UNITY-DANA. 2017, pp.271.

[8] Shipshova O.A., Nurtdinov I.I., etc. A role of multinational corporations in processes of globalization of economy. Economy and management: problems, decisions. 2019, vol. 5, 1, pp. 8-15.

[9] Alexsandr S. Kuznetsov. Russian Professor's meeting. Russian Journal of Physical Education and Sport. 2019, 14(1), pp. 17-22. DOI: 10.14526/2070-4798-2019-14-1-18-24

[10] Shipshova O.A., Mukhametshina F.A. Trends of development of the trade industry of Russia in the conditions of globalization of economy. the Scientific review. 2016, 10, pp. 173-176.10. URL: http://www.forbes.com/companies/flextronics-international/ 